\title{
Pengaruh Kepemimpinan terhadap Kinerja Karyawan pada PT. SAMKO Indonesia
}

\author{
${ }^{1}$ Amirudin*, ${ }^{2}$ Aris Ariyanto \\ ${ }^{1,2}$, Universitas Pamulang
}

\author{
Alamat Surat \\ Email: ${ }^{1}$ dosen02595@unpam.ac.id*,2dosen02492@unpam.ac.id
}

Article History:

Received: 10-Nopember-2020; Received in Revised: 25-Nopember-2020; Accepted: 30-Nopember-2020

\begin{abstract}
ABSTRAK
Penelitian ini bertujuan untuk mengetahui pengaruh kepemimpinan terhadap kinerja karyawan pada PT. Samko Indonesia. Metode yang digunakan adalah explanatory research dengan sampel sebanyak 74 responden. Teknik analisis menggunakan analisis statistik dengan pengujian regresi, korelasi, determinasi dan uji hipotesis. Hasil penelitian ini variabel kepemimpinan diperoleh nilai rata-rata skor sebesar 3,39 dengan kriteria kurang baik. Variabel kinerja karyawan diperoleh nilai rata-rata skor sebesar 3,79 dengan kriteria kurang baik. Kepemimpinan berpengaruh positif dan signifikan terhadap kinerja karyawan dengan nilai persamaan regresi $\mathrm{Y}=11,377+0,784 \mathrm{X}$, dan nilai koefisien korelasi 0,762 atau memiliki tingkat hubungan yang kuat dengan nilai determinasi $58,1 \%$. Uji hipotesis diperoleh signifikansi $0,000<0,05$.
\end{abstract}

\section{Kata kunci: Kepemimpinan, Kinerja Karyawan}

\section{ABSTRACT}

This study aims to determine the effect of leadership on employee performance at PT. Samko Indonesia. The method used is explanatory research with a sample of 74 respondents. The analysis technique uses statistical analysis with regression testing, correlation, determination, and hypothesis testing. This study's results, the leadership variable, obtained an average score of 3.39 with unfavorable criteria. Employee performance variables obtained an average score of 3.79 with unfavorable criteria. Leadership has a positive and significant effect on employee performance with the regression equation value $Y=11.377+0.784 X$, and the correlation coefficient value is 0.762 or has a strong relationship with a determination value of $58.1 \%$. Hypothesis testing obtained a significance of $0.000<0.05$.

Keywords: Leadership, Employee Performance

\section{PENDAHULUAN}

Sumber daya manusia (SDM) merupakan salah satu faktor kunci dalam reformasi ekonomi, yakni bagaimana menciptakan SDM yang berkualitas dan memiliki keterampilan serta berdaya saing tinggi dalam persaingan global. Manusia selalu berkembang aktif dan dominan dalam setiap kegiatan organisasi, karena manusia menjadi perencana, pelaku, dan penentu terwujudnya tujuan organisasi. Tujuan tidak mungkin terwujud tanpa peran aktif karyawan meskipun alat-alat yang dipergunakan canggih. Alat-alat canggih yang dimiliki tidak ada manfaatnya jika peran aktif karyawan tidak diikutsertakan. Mengatur karyawan adalah sulit dan kompleks, karena mereka mempunyai pikiran, perasaan, status, keinginan, dan latar belakang yang heterogen yang dibawa kedalam organisasi, maka dari itu peran kepemimpinan yang efektif sangatlah penting. 
Agar perusahaan mampu terus bertahan dan bersaing, dominasi teknologi saja tidak cukup jika tidak ditunjang oleh SDM yang handal, sehingga investasi dalam sumber daya ekonomi yang paling berharga, yaitu SDM tidak dapat ditunda lagi, dari sudut manajemen, seorang pemimpin harus mampu menetapkan tujuan yang hendak dicapai oleh organisasi atau perusahaan, dalam konteks ini seorang pemimpn harus mampu merancang teknik dan strategi yang tepat. Selain mampu membuat teknik dan strategi yang jitu, seorang pemimpin juga dituntut untuk mampu mengambil keputusan yang cepat dan tepat. Sebab, terlambat dalam mengambil keputusan dapat merugikan organisasi, demikian juga salah dalam mengambil keputusan tentunya harus berhadapan dengan sejumlah konsekuensi seperti dana, waktu, dan tenaga. Apabila seorang pemimpin ingin mencapai tujuannya dengan efektif, maka harus mempunyai kewenangan untuk memimpin para bawahannyadalam usaha mencapai tujuan tersebut.

Pentingnya kinerja karyawan Dinas Pemadam Kebakaran Dan Penyelamatan adalah proses yang digunakan untuk memberikan manfaat pekerjaan yang baik jika dikerjakan dengan benar, dan mengukur sejauh mana kinerja karyawan Dinas Pemadam Kebakaran Dan Penyelamatan, hal ini memberikan manfaat yang penting bagi para karyawan maupun pimpinan dalam suatu organisasi, dan hasil evaluasi kinerja dapat dilakukan untuk menentukan tindakan yang tepat. Dan pentingnya kinerja karyawan perlu dicermati untuk mengetahui kemampuan karyawan, penerimaan tujuan karyawan, tingkat tujuan yang dicapai, dan interaksi antara tujuan dan kemampuan para karyawan dalam perusahaan dimana masing-masing elemen tersebut berpengaruh terhadap kinerja seseorang.

Kepemimpinan yang ada di PT. Samko Indonesia dipimpin oleh Kepala Pimpinan yang membawahi banyak karyawan membutuhkan kepemimpinan yang baik sehingga PT. Samko Indonesia dapat menciptakan pelayanan yang maksimal kepada masyarakat yang ada di wilayah tersebut. Sehubungan dengan hal tersebut diatas, maka penulis tertarik untuk mengamati, melihat dan melakukan penelitian tentang bagaimana pengaruh kepemimpinan terhadap kinerja karyawan pada Dinas Kebakaran Dan Penyelamatan Tangerang Selatan, dan dari uraian tersebut penulis akan melakukan penelitian dengan judul "Pengaruh Kepemimpinan Terhadap Kinerja Karyawan Pada PT. Samko Indonesia".

\subsection{Kajian Pustaka}

Pada sebuah organisasi pemerintahan, kesuksesan atau kegagalan dalam pelaksanaan tugas dan penyelenggaraan pemerintahan, dipengaruhi oleh kepemimpinan, melalui kepemimpinan dan di dukung oleh kapasitas organisasi pemerintahan yang memadai, maka penyelenggaraan tata pemerintahan yang baik (Good Govermance) akan terwujud, sebaliknya kelemahan kepemimpinan merupakan salah satu sebab keruntuhan kinerja birokrasi di Indonesia. Istianto (2009: 2). Kepemimpinan adalah cara seorang pemimpin mempengaruhi perilaku bawahan agar mau bekerjasama dan bekerja secara produktif untuk mencapai tujuan organisasi, Malayu Hasibuan (2010: 67). Menurut Robbins (2010) Kepemimpinan adalah kemampuan untuk mempengaruhi suatu kelompok kearah suatu tujuan. Kepemimpinan adalah pengaruh antara pribadi yang dijalankan dalam situasi tertentu serta diarahkan melalui proses komunikasi kearah pencapaian satu atau beberapa tujuan tersebut. Kepemimpinan (leadership) dapat dikatakan sebagai cara dari seorang pemimpin (leader) dalam mengarahkan, mendorong dan mengatur seluruh unsur-unsur di dalam kelompok atau organisasinya untuk mencapai suatu tujuan organisasi yang diinginkan sehingga menghasilkan kinerja karyawan yang maksimal. Dengan meningkatnya kinerja karyawan berarti tercapainya hasil kerja seseorang atau karyawan dalam mewujudkan organisasi, maka harus adanya komunikasi antara atasan dan bawahan yang optimal, kerja sama antar karyawan dalam bekerja, harus adanya motivasi dari atasan yang diberikan kebawahan dan harus optimalnya kinerja karyawan dan rasa tanggung jawab karyawan. Pemimpin $($ Leader $=$ Head $)$ adalah seorang pemimpin yang dalam melaksanakan kepemimpinannya hanya atas kekuasaan (power) yang dimilikinya. Falsafah kepemimpinannya bahwa bawahan adalah untuk pemimpin. Pemimpin menganggap dirinya paling berkuasa, paling cakap, sedangkan bawahan dianggap hanya pelaksana keputusan-keputusannya saja. Pelaksanaan kepemimpinannya dengan memberikan instruksi/ perintah-perintah, ancaman sangsi, dan 
pengawasan yang ketat. Pelaksanaan kepemimpinannya cenderung menumbuhkan kepercayaan, partisipasi, loyalitas, dan internal motivasi para bawahan dengan cara persuasif. Hal ini sesuai akan diperoleh karena kecakapan, kemampuan, dan perilakunya.

Menurut Sri Rahmi (2014: 19) kepemimpinan merupakan suatu kemampuan seseorang pemimpin untuk mempengaruhi, memotivasi, dan memungkinkan orang lain untuk berkontribusi terhadap efektivitas dan keberhasilan organisasi. Artinya sisi keefektifan sumberdaya organisasi dalam mencapai tujuan organisasi yang perlu dicapai secara efektif, jadi dapat dikatakan kepemimpinan yang efektif ialah yang dapat mempengaruhi orang lain sehingga mereka termotivasi untuk memberikan kontribusi pada pencapaian kelompok. Menurut Hasibuan (2011: 43) Kepemimpinan adalah seseorang dengan wewenang kepemimpinannya mengarahkan bawahannya untuk mengerjakan sebagian dari pekerjaannya dalam mencapai tujuan. Jadi pemimpin harus mempunyai bawahan, harus membagi pekerjaannya dan harus tetap bertanggung jawab terhadap pekerjaan tersebut. Menurut Robert Tanembaum (2011: 43) Kepemimpinan adalah mereka yang menggunakan wewenang untuk mengorganisasi, mengarahkan, mengontrol para bawahan yang bertanggung jawab, supaya semua bagian pekerjaan dikoordinasi demi pencapaian tujuan perusahaan. Dalam organisasi kinerja adalah jawaban dari berhasilnya atau tidaknya tujuan organisasi yang telah ditetapkan. Pemimpin perusahaan atau manajer seringkali mengabaikan dan tidak memperhatikan masalah kinerja kecuali kalau sudah amat buruk, terlalu sering tidak mengetahui betapa buruknya kinerja telah merosot sehingga perusahaan atau instansi menghadapi krisis yang serius. Kinerja harus dilakukan dengan efektif dan efisien yang artinya dalam melaksanakan pekerjaan organisasi dengan menggunakan sumberdaya organisasi itu harus dilakukan dengan cermat dan teliti agar tidak terjadi pemborosn. Kinerja yang baik dan berkualitas bisa berakhibat baik juga bukan hanya dari perusahaan atau instansi tersebut tetapi bagi karyawan atau pegawi dari perusahaan itu sendiri, bahkan dapat dirasakan oleh masyarakat luas.

Menurut M. Ma'ruf (2014: 3) Kinerja adalah prestasi kerja yang merupakan hasil dari implementasi rencana kerja yang dibuat suatu istitusi yang dilaksanakan oleh pimpinan dan karyawan atau karyawan (SDM) yang bekerja diintitusi itu baik pemerintah maupun perusahaan bisnis untuk mencapaai tujuan organisasi. Menurut Simanjuntak (2011: 1) Kinerja adalah tingkat pencapaian hasil atas pelaksanaan tugas tertentu. Sedangkan kinerja perusahaan adalah tingkat pencapaian hasil dalam rangka mewujudkan tujuan perusahaan. Menurut Moeheriono dalam Abdullah (2014: 3) Kinerja atau performance merupakan gambaran mengenai tingkat pencapaian pelaksanaan suatu program kegiatan atau kebijakan dalam mewujudkan sasaran, tujuan, visi dan misi organisasi yang dituangkan melalui perencanaan strategis atau suatu organisasi. Dari berbagai pengertian tentang kinerja diatas dapat disimpukan bahwa kinerja adalah merupakan pencapaian hasil kerja dari implementasi kerja yang dibuat oleh suatu institusi dalam mewujudkan sasaran, tujuan, visi dan misi organisasi yang dituangkan melalui perencanaan strategis suatu organisasi. Terdapat Pedoman Aperatur Negara, Pedoman tersebut merupakan pedoman dalam melaksanakan kinerja kerja aparatur negara pada lingkungan instansi atau lembaga masing-masing, untuk menumbuhkan dan meningkatkan semangat kerja, kepemimpinan dan tanggung jawab moral aparaturnya secara terus-menerus dan konsisten, sesuai dengan tugas dan fungsi masing-masing. Menurut Wirawan (2009: 5), kinerja adalah keluaran yang dihasilkan oleh fungsi-fungsi atau indikator-indikator suatu pekerjaan atau suatu profesi dalam waktu tertentu. Menurut Irham Fahmi (2013: 2), kinerja adalah hasil yang diperoleh suatu organisasi baik organisasi tersebut bersifat profit oriented dan non profit oriented yang dihasilkan selama satu periode tertentu. Definisi dari kinerja merupakan suatu hasil kerja yang dihasilkan oleh seorang karyawan dalam melaksanakan tanggung jawabnya di dalam suatu organisasi yang dilakukan dalam suatu periode tertentu.

\section{METODE}

Jenis penelitian yang dipakai adalah asosiatif, dimana tujuannya adalah untuk mengetahui mencari keterhubungan antara variabel independen terhadap variabel dependennya. Populasi dalam penelitian ini berjumlah 74 responden yaitu karyawan PT. Samko Indonesia. Teknik pengambilan 
sampling dalam penelitian ini adalah samplel jenuh, dimana semua anggota populasi dijadikan sebagai sampel. Dengan demikian sampel dalam penelitian ini berjumlah 74 responden. Dalam menganalisis data digunakan uji validitas, uji reliabilitas, analisis regresi linier sederhana, koefisien korelasi, koefisien determinasi dan uji hipotesis.

\section{HASIL DAN PEMBAHASAN}

\subsection{Hasil}

Pada pengujian ini digunakan untuk mengetahui skor minimum dan maksimum skor tertinggi, ratting score dan standar deviasi dari masing-masing variabel. Adapun hasilnya sebagai berikut:

Tabel 1. Hasil Analisis Descriptive Statistics

Descriptive Statistics

\begin{tabular}{lrrrrr}
\hline & N & Minimum & Maximum & Mean & Std. Deviation \\
\hline Kepemimpinan (X1) & 74 & 28 & 44 & 33.89 & 4.022 \\
Kinerja Karyawan (Y) & 74 & 29 & 49 & 37.93 & 4.136 \\
Valid N (listwise) & 74 & & & & \\
\hline
\end{tabular}

Kepemimpinan diperoleh varians minimum sebesar 28 dan varians maximum 44 dengan ratting score sebesar 3,39 dengan standar deviasi 4,022. Kinerja karyawan diperoleh varians minimum sebesar 29 dan varians maximum 49 dengan ratting score sebesar 3,79 dengan standar deviasi 4,136.

\section{Analisis Verifikatif.}

Pada analisis ini dimaksudkan untuk mengetahui pengaruh variabel independen terhadap variabel dependen. Adapun hasil pengujian sebagai berikut:

\section{Analisis Regresi Linier Sederhana}

Uji regresi ini dimaksudkan untuk mengetahui perubahan variabel dependen jika variabel independen mengalami perubahan. Adapun hasil pengujiannya sebagai berikut:

Tabel 2. Hasil Pengujian Regresi Linier Sederhana

\section{Coefficients $^{\mathrm{a}}$}

\begin{tabular}{lrrrrrr} 
& \multicolumn{2}{c}{$\begin{array}{c}\text { Unstandardized } \\
\text { Coefficients }\end{array}$} & \multicolumn{2}{c}{$\begin{array}{c}\text { Standardized } \\
\text { Coefficients }\end{array}$} & & \\
\cline { 2 - 5 } Model & \multicolumn{1}{c}{ B } & Std. Error & Beta & & t & Sig. \\
\hline 1 (Constant) & 11.377 & 2.678 & & & 4.249 & .000 \\
Kepemimpinan $(\mathrm{X})$ & .784 & .078 & & .762 & 9.986 & .000 \\
\hline
\end{tabular}

Berdasarkan hasil pengujian pada tabel di atas, diperoleh persamaan regresi $\mathrm{Y}=11,377+0,784 \mathrm{X}$. Dari persamaan tersebut dijelaskan sebagai berikut:

1) Konstanta sebesar 11,377 diartikan jika kepemimpinan tidak ada, maka telah terdapat nilai kinerja karyawan sebesar 11,377 point.

2) Koefisien regresi kepemimpinan sebesar 0,784 , angka ini positif artinya setiap ada peningkatan kepemimpinan sebesar 0,784 point maka kinerja karyawan juga akan mengalami peningkatan sebesar 0,784 point.

\section{Analisis Koefisien Korelasi}

Analisis koefisien korelasi dimaksudkan untuk mengetahui tingkt kekuatan hubungan dari variabel independen terhadap variabel dependen baik secara parsial maupun simultan. Adapun hasil pengujian sebagai berikut: 
Tabel 3. Hasil Pengujian Koefisien Korelasi Kepemimpinan Terhadap Kinerja Karyawan.

\section{Correlation $\mathbf{s}^{\mathbf{b}}$}

\begin{tabular}{llrr}
\hline & & $\begin{array}{c}\text { Kepemimpinan } \\
(\mathrm{X} 1)\end{array}$ & $\begin{array}{r}\text { Kinerja Karyawan } \\
(\mathrm{Y})\end{array}$ \\
\hline Kepemimpinan (X1) & Pearson Correlation & 1 & $.762^{* *}$ \\
& Sig. (2-tailed) & & .000 \\
Kinerja Karyawan (Y) & Pearson Correlation & $.762^{* *}$ & 1 \\
& Sig. (2-tailed) & .000 & \\
\hline
\end{tabular}

Berdasarkan hasil pengujian diperoleh nilai korelasi sebesar 0,762 artinya kepemimpinan memiliki hubungan yang kuat terhadap kinerja karyawan.

\section{Analisis Koefisien Determinasi}

Analisis koefisien determinasi dimaksudkan untuk mengetahui besarnya persentase pengaruh dari variabel independen terhadap variabel dependen. Adapun hasil pengujian sebagai berikut:

Tabel 4. Hasil Pengujian Koefisien Determinasi Kepemimpinan Terhadap Kinerja Karyawan.

\begin{tabular}{|c|c|c|c|c|}
\hline \multicolumn{5}{|c|}{ Model Summary } \\
\hline Model & $\mathrm{R}$ & R Square & $\begin{array}{l}\text { Adjusted R } \\
\text { Square }\end{array}$ & $\begin{array}{l}\text { Std. Error of the } \\
\text { Estimate }\end{array}$ \\
\hline 1 & $.762^{\mathrm{a}}$ & .581 & .575 & 2.697 \\
\hline
\end{tabular}

Berdasarkan hasil pengujian diperoleh nilai determinasi sebesar 0,581 artinya kepemimpinan memiliki kontribusi pengaruh sebesar $58,1 \%$ terhadap kinerja karyawan.

\section{Uji Hipotesis}

Pengujian hipotesis dengan uji t digunakan untuk mengetahui hipotesis mana yang diterima. Rumusan hipotesis: Terdapat pengaruh yang signifikan antara kepemimpinan terhadap kinerja karyawan.

Tabel 5. Hasil Uji Hipotesis Kepemimpinan Terhadap Kinerja Karyawan.

\section{Coefficients $^{\mathrm{a}}$}

\begin{tabular}{llrrrrr}
\hline & \multicolumn{2}{c}{$\begin{array}{c}\text { Unstandardized } \\
\text { Coefficients }\end{array}$} & \multicolumn{2}{c}{$\begin{array}{c}\text { Standardized } \\
\text { Coefficients }\end{array}$} & & \\
\cline { 2 - 5 } Model & \multicolumn{1}{c}{ B } & Std. Error & Beta & & \multicolumn{1}{c}{ Sig. } \\
\hline 1 & (Constant) & 11.377 & 2.678 & & 4.249 & .000 \\
& Kepemimpinan $(X)$ & .784 & .078 & .762 & 9.986 & .000 \\
\hline
\end{tabular}

Berdasarkan hasil pengujian pada tabel di atas, diperoleh nilai t hitung $>\mathrm{t}$ tabel atau $(9,986>1,994)$, dengan demikian hipotesis yang diajukan bahwa terdapat pengaruh yang signifikan atara kepemimpinan terhadap kinerja karyawan diterima.

\subsection{Pembahasan}

\section{Kondisi Jawaban Responden Variabel Kepemimpinan}

Berdasarkan jawaban responden, variabel kepemimpinan diperoleh ratting score sebesar 3,39. Skor ini masih kurang baik artinya ada beberapa indikator yang masih harus diperbaiki sehingga tercipta kepemiminan yang ideal 


\section{Kondisi Jawaban Responden Variabel Kinerja Karyawan}

Berdasarkan jawaban responden, variabel kinerja karyawan diperoleh ratting score sebesar 3,79 Skor ini masih kurang baik artinya ada beberapa indikator yang masih harus diperbaiki sehingga karyawan mampu mengoptimslksn kinerjanya

\section{Pengaruh Kepemimpinan Terhadap Kinerja Karyawan}

Kepemimpinan berpengaruh signifikan terhadap kinerja karyawan dengan persamaan regresi $\mathrm{Y}$ $=11,377+0,784 \mathrm{X}$, nilai korelasi sebesar 0,762 atau memiliki hubungan yang kuat dengan kontribusi pengaruh sebesar 58,1\%. Pengujian hipotesis diperoleh nilai t hitung $>\mathrm{t}$ tabel atau $(9,986>1,994)$. Dengan demikian hipotesis yang diajukan bahwa terdapat berpengaruh signifikan antara kepemimpinan terhadap kinerja karyawan diterima.

\section{KESIMPULAN}

\subsection{Kesimpulan}

a. Variabel kepemimpinan diperoleh ratting score sebesar 3,39. Skor ini masih kurang baik artinya ada beberapa indikator yang masih harus diperbaiki sehingga tercipta kepemiminan yang ideal

b. Variabel kinerja karyawan diperoleh ratting score sebesar 3,79. Skor ini masih kurang baik artinya ada beberapa indikator yang masih harus diperbaiki sehingga karyawan mampu mengoptimslksn kinerjanya

c. Kepemimpinan berpengaruh signifikan terhadap kinerja karyawan dengan persamaan regresi $\mathrm{Y}$ $=11,377+0,784 \mathrm{X}$, nilai korelasi sebesar 0,762 atau kuat dan kontribusi pengaruh sebesar 58,1\% sedangkan sisanya sebesar 57,9\% dipengaruhi faktor lain. Uji hipotesis diperoleh nilai t hitung > t tabel atau $(9,986>1,994)$.

\subsection{Saran}

a. Pimpinan harus mampu memberikan contoh bekerja secara efektif sehingga karyawan mampu mencontohnya.

b. Kinerja perusahaan dapat ditingkatkan dengan memberdayakan karyawan dengan menegakkan peraturan yang baik dan pemberian motivasi yang lebih inten lagi.

\section{DAFTAR PUSTAKA}

Abdullah, M (2014) Manajemen dan Evaluasi Kinerja Karyawan, Yogyakarta: Penerbit Aswaja Pressindo.

Algifari. (2015). “Analisis Regresi untuk Bisnis dan Ekonomi”. Yogyakarta: BPFE.

Arikunto, Suharsimi (2014). “Prosedur Penelitian Suatu Pendekatan Praktek”. Jakarta: Rineka Cipta.

Bangun, Wilson. 2012. “Manajemen Sumber Daya Manusia”. Jakarta: Erlangga

Bejo Siswanto (2013) Manajemen Tenaga Kerja Rancangan dalam Pendayagunaan dan Pengembangan Unsur Tenaga Kerja”, Bandung: Sinar Baru.

Dessler, G. (2006.) Manajemen Sumber Daya Manusia (Jilid II). Jakarta: Indeks.

Edi Sutrisno (2016). Manajemen Sumber Daya Manusia. Jakarta: Prenadamedia Group.

Edi Sutrisno (2016). Manajemen Sumber Daya Manusia. Jakarta: Prenadamedia Group.

George Terry R \& Rue, Leslie W. Rue (2016) Dasar-Dasar Manajemen, Jakarta Bumi Aksara.

Gerry Dessler (2016) Human Resources Management, Prenticehall, London: International Inc.

Handoko (2016) Manajemen Personalia dan Sumberdaya Manusia. Yogyakarta: BPFE.

Handoko T. Hani, (2012), Manajemen Personalia dan Sumber Daya Manusia, edisi kedua, BPFE, Yogyakarta 
Hasibuan, Malayu S.P. (2016). Manajemen Sumber Daya Manusia. Edisi Revisi. Jakarta: PT Bumi Aksara.

Haudi, H. W., \& Cahyono, Y. (2020). Analysis of Most Influential Factors To Attract Foreign Direct Investment. Journal of Critical Reviews, 7(13), 4128-4135.

Imam Ghozali (2017). “Aplikasi Analisis Multivariate Dengan Program SPSS”. Edisi Kelima. Semarang: Badan Penerbit Undip.

Istijanto (2014) “Riset Sumber Daya Manusia”. Jakarta: PT. Gramedia Pustaka

Jasmani, J., \& Paeno, P. (2019). The Effect of Leadership and Competence on Lecturer Performance and Its Implications on Student Learning Motivation at Pamulang University. International Journal of Advances in Social and Economics, 1(4).

Jasmani, J., Maduningtias, L., \& Irmal, I. (2019). Pelatihan Dan Penguasaan Digital Marketing Dalam Meningkatkan Pendapatan Para Remaja Di Lingkungan Benda Timur IV. Jurnal Pengabdian Dharma Laksana, 2(1), 65-68.

Kharis, Ismu Fadli (2011). "Studi Mengenai Impulse Buying dalam Penjualan Online”. Semarang : Skripsi Universitas Diponegoro

Luthans Fred (2014) Organizational Behavior, Ney York: McGraw-Hill, New York.

Mangkunegara, Prabu Anwar. (2016). Evaluasi Kinerja SDM. Cetakan ke tujuh, PT Refika Aditama: Bandung.

Pranoto, P., Jasmani, J., \& Marayasa, I. N. (2019). Pelatihan Digital Marketing Untuk Peningkatan Perekonomian Anggota Karang Taruna Al Barkah Di Kampung Cicayur-Tangerang. Jurnal Pengabdian Dharma Laksana, 1(2), 250-258.

Rao, Purba, (2012). "Measuring Consumer Perceptions Through Factor Analysis", The Asian.

Rozi, A., \& Sunarsi, D. (2020). The Influence of Motivation and Work Experience on Employee Performance at PT. Yamaha Saka Motor in South Tangerang. Jurnal Office, 5(2), 65-74.

Santoso, Singgih (2015). “Menguasai Statistik Multivariat”. Jakarta: PT Elex Media Komputindo.

Sedarmayanti (2016) Manajemen Sumber Daya Manusia, Reformasi Birokrasi dan Manajemen Karyawan Negeri Sipil, Cetakan Kelima, Bandung: PT Refika Aditama.

Sobarna, A., Hambali, S., Sutiswo, S., \& Sunarsi, D. (2020). The influence learning used ABC run exercise on the sprint capabilities. Jurnal Konseling dan Pendidikan, 8(2), 67-71.

Sunarsi, D., Wijoyo, H., Prasada, D., \& Andi, D. (2020, September). Pengaruh Lingkungan Kerja Terhadap Kinerja Karyawan pada PT. Mentari Persada di Jakarta. In Seminar Nasional Manajemen, Ekonomi, Akuntansi (Vol. 5, No. 1, pp. 117-123).

Sudjana (2014) “Metode Statistika”, Bandung: Tarsido.

Sugiyono (2017), "Metode Penelitian Administrasi : dilengkapi dengan Metode $R \& D$ ". Bandung: Alfabeta.

Suhartanto (2014). “Metode Riset Pemasaran”. Bandung: Alfabeta

Sunarsi, D. (2018). Buku Ajar: Seminar Perencanaan Sumber Daya Manusia. Tangerang Selatan: Asmoro Mediatama

Sunarsi, D. (2018). Pengembangan Sumber Daya Manusia Strategik \& Karakterisrik Sistem Pendukungnya : Sebuah Tinjauan. Jurnal Ilmiah MEA (Manajemen, Ekonomi, \& Akuntansi), 2(3), 178 - 194.

Sunarsi, D. (2019). Seminar Sumber Daya Manusia. Tangerang Selatan: Unpam Press 
Sutrisno, S., \& Sunarsi, D. (2019). The Effect of Work Motivation and Discipline on Employee Productivity at PT. Anugerah Agung in Jakarta. Jurnal Ad'ministrare, 6(2), 187-196.

Veithzal Rivai (2015) Manajemen Sumber Daya Manusia Untuk Perusahaan, Jakarta: Raja Grafindo Persada.

Wibowo (2015) Manajemen Kinerja, Jakarta: PT. Raja Grafindo Persada. 